\title{
DESA DALAM ADMINISTRASI PUBLIK INDONESIA KONTEMPORER: PENGUATAN PERAN LAN
}

\section{VILLAGE WITHIN CONTEMPORARY INDONESIAN PUBLIC ADMINISTRATION: STRENGTHENING NIPA'S ROLE}

\author{
Rusman Nurjaman ${ }^{1}$ dan Antonius Galih Prasetyo ${ }^{2}$ \\ Pusat Kajian Desentralisasi dan Otonomi Daerah ${ }^{1}$ \\ Pusat Inovasi Tata Pemerintahan ${ }^{2}$ \\ Lembaga Administrasi Negara \\ Jalan Veteran No. 10, Gambir, Jakarta Pusat 10110 \\ Email: roesnoerjaman@gmail.com; antgalihpasetyo@gmail.com
}

Naskah diterima: 13 November 2017; revisi terakhir: 13 Maret 2018; disetujui: 9 April 2018

\begin{abstract}
Law No. 6 of 2014 on Villages provides a momentum and wide opportunities to make the village as the subject of development as well as placing it as a new axis of the national development based on the principle of participation, accountability, mutual cooperation, empowerment, sustainability, local wisdom, and independence. In another context, this Law also provides a new perspective on public administration in Indonesia. Affirmation of the principle of recognition and subsidiarity puts villages outside the hierarchial framework of the government. Unfortunately, this reality is often not considered by the national and local government with the right policies and approaches. National Institute of Public Administration (NIPA) responds to this situation by conducting a number of relevant researches. Following the ratification of Law on Villages, LAN has conducted a series of studies on villages that resulted in interesting findings that can be used to reflect the village position in the contemporary public administration order. There are three clusters of public administration issues that can be drawn from those researches, among them are the relationship between village and supravillage government, village authority, and the capacity of village governemnt. In the future, it is expected that LAN continues to play a role in developing village. Not only through research activities, but also through public administration innovation, apparatus training, and higher education of administration.
\end{abstract}

Keyword: Village, public administration, NIPA, think tank, recognition, subsidiarity 


\begin{abstract}
Abstrak
UU No. 6 Tahun 2014 tentang Desa memberikan momentum dan peluang yang lebar untuk menjadikan desa sebagai subjek pembangunan sekaligus menempatkannya sebagai poros baru pembangunan nasional yang bertumpu pada prinsip partisipasi, akuntabilitas, kegotongroyongan, pemberdayaan, keberlanjutan, kearifan lokal, dan kemandirian. Dalam konteks lain, UU ini juga memberikan perspektif baru mengenai administrasi negara di Indonesia. Penegasan asas rekognisi dan subsidiaritas desa menempatkan desa di luar kerangka hierarkial pemerintahan. Sayangnya, kenyataan ini kadang tidak disadari oleh pemerintah dan daerah melalui kebijakan dan pendekatan yang tepat. Lembaga Administrasi Negara(LAN) merespons hal ini dengan melaksanakan sejumlah kajian terkait. Pasca pengesahan UU Desa, LAN telah menyelenggarakan kajian mengenai desa dengan berbagai temuan menarik yang dapat dipakai untuk merefleksikan posisi desa dalam tatanan administrasi negara kontemporer. Ada tiga klaster isu administrasi negara yang dapat ditarik dari berbagai kajian tersebut, di antaranya hubungan desa dengan pemerintah supradesa, kewenangan desa, dan kapasitas pemerintah desa. Di masa depan, diharapkan LAN terus berperan dalam memajukan desa. Tidak saja melalui kegiatan kajian, namun juga melalui inovasi administrasi negara, diklat aparatur, dan pendidikan tinggi administrasi.
\end{abstract}

Kata Kunci: Desa, administrasi negara, LAN, think tank, rekognisi, subsidiaritas.

\title{
A. PENDAHULUAN
}

Desa merupakan entitas yang unik dengan latar belakang historis yang panjang dan profil sosiologis yang khas. Keberadaannya senantiasa membuahkan tafsir dan kontestasi yang berkelanjutan di antara berbagai aktor dan kepentingan. Negara memandang, mendekati, dan memperlakukan desa dengan berbagai instrumen kebijakan yang tergelar sejak kemerdekaan. Dalam lintasan sejarah republik ini, telah banyak kebijakan yang dikeluarkan pemerintah untuk mengatur desa, mulai dari UU No 19 Tahun 1965 tentang Desa Praja, UU No. 5 Tahun 1979 tentang Pemerintah Desa, hingga PP No. 72 Tahun 2005 tentang Desa yang merupakan turunan dari UU No. 32 Tahun 2004 tentang Pemerintah Daerah. Bahkan, kebijakan pengaturan desa juga telah dibuat sejak era prakolonial dan kolonial karena desa pada kenyataannya memang telah eksis sebelum negara ada. Terakhir, pada 15 Januari 2014, disahkan Undang-undang (UU) No. 6 Tahun 2014 tentang Desa.

Kebijakan terakhir ini disambut antusias oleh banyak kalangan, mulai dari aktivis, pemerhati, dan masyarakat desa itu sendiri. Setelah perjuangan yang panjang selama tujuh tahun (2007-2013), akhirnya UU ini dapat dilahirkan. Antusiasme tersebut muncul karena di dalam UU No. 6/2014 terkandung pendekatan yang berbeda dari pemerintah dalam memandang desa. Berbeda dengan berbagai kebijakan sebelumnya, pemerintah mulai menempatkan dan memperlakukan desa sebagaimana fitrahnya. Desa diakui sebagai kesatuan masyarakat hukum yang mempunyai karakter ganda sebagai masyarakat berpemerintahan (self-governing community) dan pemerintahan lokal (local self-government). Dalam konstruksi demikian, susunan asli, hak asal-usul, dan kedaulatan politik desa direstitusi secara tegas. Ini merupakan antitesis dari pendekatan yang telah berlangsung selama sekian dekade yang menempatkan desa sebagai obyek pembangunan dan wilayah administratif terendah yang melayani berbagai institusi supradesa.

Dari perspektif administrasi negara, rezim baru desa yang muncul pasca UU No. 6/2014 menyajikan tantangan konseptual sekaligus praktikal. Ada banyak pertanyaan dan perspektif yang 
dapat digunakan untuk membedah rezim baru desa tersebut dari sisi administrasi negara, mulai dari tata hubungan dan kewenangan dalam kaitannya dengan pemerintah (pusat dan daerah) sampai dengan tata kelolanya.Tidak hanya menjadi perhatian akademisi dan aktivis desa, banyak institusi pemerintahan juga berkepentingan dalam merespons isu besar tersebut. Salah satunya adalah Lembaga Administrasi Negara (LAN).

Sebagai institusi yang memiliki visi "menjadi rujukan bangsa dalam pembaharuan administrasi negara" dan secara historis dibentuk salah satunya untuk mengembangkan sistem administrasi pemerintahan, LAN memiliki kepentingan untuk terlibat dalam diskursus desa. Desa adalah bagian dari sistem administrasi negara nasional dan pembaharuan desa adalah fragmen dari pembaharuan administrasi negara secara keseluruhan. Arah dari keterlibatan tersebut tentunya sesuai dengan tugas pokok dan fungsi yang diamanahkan kepada LAN, antara lain diklat aparatur, kajian kebijakan, inovasi administrasi negara, dan penyelenggaraan pendidikan tinggi administrasi.

Sesungguhnya, keterlibatan dan hubungan LAN dengan desa bukanlah sesuatu yang asing. Pada tahun 1983 misalnya, LAN bekerjasama dengan Ditjen Pembangunan Desa dan Pemerintah Prancis c.q. IIAP (Institute International d'Administration Publique) menyelenggarakan temu karya “Administrasi Pembangunan Pedesaan dengan Aspek Khusus Kepemimpinan Pedesaan” yang ditindaklanjuti dengan kunjungan lapangan ke suatu desa di Sulawesi Selatan (LAN, 1990: 23). Kini, seiring dengan lahirnya UU No. 6/2014 yang membawa paradigma baru tentang desa, keterlibatan LAN menjadi lebih urgen dan dinantikan. Pemangku kepentingan membutuhkan kontribusi LAN dalam memajukan dan mendukung desa, selaras dengan tugas dan fungsi yang diembannya.

Sejak UU No. 6/2014 disahkan, LAN telah melakukan beberapa kegiatan terkait desa. Misalnya seminar nasional “Akselerasi Inovasi di Tingkat Desa dalam Mewujudkan Desa Inovatif di Indonesia” yang diselenggarakan pada 8 Desember 2016 di LAN Jakarta (http://lan.go.id/id/beritalan/desa-harus-inovatif-dengan-program-kerja-yang-jelas). Hal lain yang cukup banyak dilakukan adalah mengadakan kegiatan kajian terkait dengan desa. Tulisan ini hendak menyajikan kontribusi yang diberikan LAN dalam pengayaan diskursus tentang desa melalui kegiatan yang disebut terakhir. LAN melalui berbagai satuan kerja yang ada di dalamnya telah melakukan cukup banyak kajian tentang desa sejak UU No. 6/2014 berlaku. Berbagai temuan kunci dalam kajian tersebut menjadi titik tolak untuk merefleksikan desa dalam kaitannya dengan tatanan administrasi negara kontemporer di Indonesia.

Setidaknya terdapat empat klaster isu administrasi negara mengenai desa yang dapat ditarik dan diabstraksikan dari berbagai kajian yang telah dilakukan, yakni 1) hubungan dengan pemerintahan supradesa (PKDOD LAN, 2016); 2) kelembagaan/kewenangan desa (PKDOD LAN, 2016);3) kapasitas aparatur pemerintahan desa (PKDOD LAN, 2015; PIKSA LAN, 2015; Pusat INTAN LAN, 2015; PKP2A III LAN, 2016); 4) kaitan desa dengan tata kelola jaringan (network governance) (PIKSA LAN, 2016; PIPEL LAN, 2015). Namun demikian, kontribusi melalui kegiatan kajian saja tentu tidak cukup untuk membantu pemajuan desa. Untuk itu diadvokasikan pula mengenai pentingnya keterlibatan LAN di ranah lain, antara lain inovasi administrasi negara, diklat aparatur, pendidikan tinggi administrasi, dan advokasi.

\section{B. METODE PENELITIAN}

Studi ini dilakukan dalam kerangka studi kualitatif dengan pendekatan deskriptif, yang mengedepankan otentisitas proses dan hasil. Teknik pengumpulan data dilakukan dengan wawancara dan studi dokumen. Wawancara dilakukan terhadap sejumlah informan kunci atau narasumber terpilih 
baik di lingkup pemerintah pusat maupun daerah (kabupaten/kota). Sedangkan studi dokumen dilakukan melalui pengumpulan, pengolahan, dan analisis data sekunder, meliputi: 1) hasil kajian sebelumnya berupa laporan kajian, jurnal, majalah ilmiah dan lainnya, 2) peraturan perundangundangan, dan 3) dokumen lain yang relevan seperti pemberitaan media massa dan artikel/laporan/ naskah yang diunduh dari internet.

Selanjutnya analisis data dilakukan dengan cara mengorganisasikan data, memilah data menjadi satuan-satuan, mensintesiskannya, mencari dan menemukan pola, menemukan apa yang penting dan apa yang dipelajari, dan memutuskan apa yang akan diceritakan kepada pihak lain (Moleong, 2007:248). Dalam kajian ini, melalui analisis kualitatif dilakukan beberapa tahapan analisis data meliputi: reduksi data, penyajian data, dan penarikan kesimpulan/verifikasi data (Miles \& Hubermen, 2009).

\section{KERANGKA KONSEP}

Studi ini menempatkan LAN sebagai lembaga think tank pemerintah yang turut berkontribusi dalam perbaikan pembuatan dan implementasi kebijakan. Salah satu kebijakan yang dikawal dan diadvokasi agar berjalan sesuai dengan tujuannya adalah UU No. 6/2014. UU tersebut menyumbang wacana baru dalam administrasi publik Indnesia kontemporer melalui kehadiran konsep rekognisi dan subsidiaritas. Oleh karena itu, pada bagian berikut akan dijelaskan konsep tentang think tank dan asas rekognisi serta subsidiaritas sebagai kerangka yang menjadi pijakan konseptual bagi studi ini. Terakhir, dijelaskan secara sekilas mengenai konsep tata kelola jaringan sebagai sebuah konsep administrasi negara kontemporer yang menarik untuk dikaitkan dan dibandingkan dengan tata kelola desa dalam era pasca-lahirnya UU No. 6/2014.

\section{Think tank}

Istilah think tank bermula dari RAND Corporation sebuah lembaga non-profit yang membantu memperbaiki pembuatan kebijakan melalui penelitian dan analisis yang merujuk pada suatu lingkungan yang aman dan tertutup bagi persemaian pemikiran strategis di Amerika pasca Perang Dunia II. Think tank mulai populer pada dekade 1960-an untuk menggambarkan sekelompok spesialis yang melakukan penelitian tentang masalah-masalah kebijakan penting. UNDP (2003: 6) mendefinisikan think tank sebagai organisasi yang terlibat secara reguler dalam penelitian dan advokasi mengenai masalah apa pun yang terkait dengan kebijakan publik. Think tank bertindak sebagai jembatan antara pengetahuan dan kekuasaan dalam konteks negara demokrasi modern. Gagasan tentang think tank menghubungkan para periset dan pembuat keputusan.

Sementara James McGann (2007: 12) mendefinisikan think tank sebagai organisasi yang menghasilkan penelitian, analisis, dan saran yang berorientasi pada kebijakan publik, baik yang terkait dengan masalah-masalah domestik maupun internasional, yang memungkinkan pembuat kebijakan dan masyarakat dapat membuat keputusan yang tepat. Dengan rumusan konseptual demikian, maka terdapat tiga hal esensial untuk dapat menggambarkan kegiatan dan tantangan think tanks, yaitu memadukan aspek mutu akademis (academics), pemberian nasihat (advise), dan advokasi (advocacy) secara tepat.

Lebih lanjut, McGann membedakan dua jenis think tank, yaitu independen dan berafiliasi atau memiliki keterkaitan dengan kelompok tertentu (pemerintah, partai politik, perguruan tinggi, atau perusahaan). Dari segi struktur, terdapat lembaga think tankyang secara permanen merupakan bagian dari struktur organisasi/lembaga tertentu. Lembaga serupa ini seringkali bertindak sebagai pihak yang menjembatani komunitas akademik dengan pembuat kebijakan. Sedangkan lembaga think tank independen melayani kepentingan publik sebagai representasi suara independen yang 
menjabarkan hasil riset dasar atau terapan ke dalam bahasa yang dapat dapat dipahami, terukur, dan dapat diakses baik oleh pemangku kebijakan maupun publik.

Pada kenyataannya, think tank mengambil bentuk yang beragam di setiap negara (Stone, 2005: 2-3). Dalam Tradisi Anglo-Amerika, think tank merupakan organisasi yang relatif otonom yang terlibat dalam analisis isu kebijakan secara independen dari pemerintahan, partai politik dan kelompok kepentingan lainnya. Sementara di negara-negara Asia seperti Jepang, Korea Selatan, Taipei, dan China, think tank sering ditemukan di dalam perusahaan. Di China think tank disponsori pemerintah dan cendekiawan.Mereka sering bekerja dalam hubungan patron-klien dengan para pemimpin politik. Banyak institut di Asia Tenggara bersifat semi-independen dan seringkali memiliki interaksi yang erat dengan pemerintah, atau dengan tokoh politik individu. Contoh lembaga think tank: RAND Corporation (Amerika Serikat), NIRA (Jepang), dan Institute of Policy Studies (Singapura).

Di negara-negara maju, seperti Amerika Serikat, lembaga think tank muncul sejak lebih dari 100 tahun silam. Kemunculannya berkaitan dengan tradisi filantropis perusahaan, keterbukaan dalam proses penyusunan kebijakan, dan kepercayaan bahwa sektor swasta dapat "membantu pemerintah untuk berpikir”. Saat ini, keberadaan lembaga think tank sebagai sumber informasi dan gagasan hampir sudah tidak diragukan lagi. Mengingat peran strategis yang dimilikinya, banyak bermunculan lembaga think tank. Di negeri asalnya sendiri, di Amerika Serikat, terdapat 1736 lembaga think tank, dengan sebagian berafiliasi pada pada perguruan tinggi (universitas) dan sepertiganya berbasis di Washington DC, sebagai ibukota pemerintahan (McGann, 2007). Sementara di Indonesia, kemunculan think tank tergolong baru karena baru muncul pada awal 1970-an, yaitu ditandai dengan berdirinya CSIS tahun 1971. Meskipun demikian, kemunculan lembaga yang kemudian berevolusi menjadi think tank pemerintah berdiri lebih awal, yaitu lembaga seperti LIPI dan LAN. Artinya, jauh sebelum dekade 1970-an di Indonesia sudah berdiri think tank. Hanya saja, fungsi think tank yang melekat dalam kedua lembaga pemerintah tersebut pada masa itu belum begitu menonjol.

Pattiro (dalam Struyk, 2008) mengidentifikasi setidaknya terdapat tiga peran strategis yang dijalankan oleh sebuah think tank. Pertama, mengisi kekosongan pengetahuan, informasi dan ideide yang relevan dalam proses-proses kebijakan yang selama ini tidak diisi oleh pemerintah maupun organisasi-organisasi non pemerintah yang ada. Kedua, menjadi sparring partner dari para pembuat kebijakan, dengan melakukan penilaian atas kebijakan pemerintah, baik penilaian ketika masih berupa kebijakan usulan maupun penilaian terhadap implementasi kebijakan. Ketiga, memperkuat monitoring groups agar tuntutan atau pengawasan dari para pihak yang melakukan monitoring tersebut menjadi lebih berkualitas.

Namun demikian, tentu tidak mudah bagi lembaga think tank untuk menjalankan ketiga peran tersebut di atas. Hal ini karena sangat sulit bagi think tank untuk mengklaim bahwa hasil kajiannya menjadi dasar bagi pembuatan suatu kebijakan (Soesastro, 2008). Oleh karena itu, suatu think tank dituntut untuk terus meningkatkan mutu dan relevansi kajiannya agar dapat diperhitungkan. Intinya, kegiatan penyusunan rekomendasi kebijakan wajib mengupayakan input yang baik agar dapat menghasilkan output yang baik pula.

Lebih lanjut, menurut Soesastro, eksistensi think tank dapat dipertanggungjawabkan apabila menghasilkan kajian-kajian yang baik secara konsisten. Persoalan apakah kemudian hasil kajian tersebut dapat dimanfaatkan sebagai dasar kebijakan justru itu merupakan hal sekunder (Soesastro, 2008).

\section{Asas Rekognisi dan Subsidiaritas}

Kelahiran UU No. 6/2014 diiringi pula dengan kemunculan konsep yang “baru” dalam 
administrasi publik di Indonesia, khususnya dalam kaitannya dengan isu administrasi publik desa atau secara lebih luas isu hubungan negara dengan desa. Konsep tersebut adalah rekognisi dan subsidiaritas. Dua konsep tersebut tersurat di dalam Pasal 6 UU No. 6/2014 yang mengatur mengenai asas pengaturan desa. Kehadiran kedua asas tersebut mereformasi secara total cara pandang atas desa yang selama ini lebih banyak dibingkai dan dipandang dalam lensa konseptual seperti desentralisasi, pemerintahan semu, dan subsistem pemerintahan daerah.

Melalui dua asas tersebut, desa diletakkan dalam posisi yang lebih layak karena sesuai dengan fitrah, karakter, dan sejarahnya. Bagaimana memahami kedua asas tersebut? Asas pertama adalah rekognisi. Dalam teori sosial, konsep rekognisi muncul untuk memotret fenomena yang banyak terjadi di belahan dunia mengenai tuntutan dari sekelompok komunitas atau golongan sosial yang selama ini termarjinalkan dalam masyarakat agar keunikan atau kebutuhan mereka lebih diakui dan diperhatikan. Pengakuan tersebut dapat didasarkan pada identitas jender, etnis, ras, difabilitas, orientasi seksual, dan sebagainya. Tuntutan tersebut muncul karena adanya represi dan diskriminasi dari kelompok dominan dan institusi sosial formal (negara, sistem ekonomi) terhadap mereka. Kelompok yang dipinggirkan dihalangi untuk berpartisipasi secara penuh dalam kehidupan sosial dan politik. Mereka juga dicitrakan dalam imaji yang distortif oleh kelompok arus utama sehingga hal tersebut memengaruhi harga diri dan peluang sosial mereka. Kemunculan negara kesejahteraan juga berkontribusi terhadap politik rekognisi karena hal itu memungkinkan sebagian masyarakat untuk lepas dari tuntutan tradisional yang terkait dengan keadilan politik atau ekonomi dan beralih kepada tuntutan yang lebih bersifat identiter dan kultural (Chriss, 2007: 3828).

Meskipun desa sebagai kesatuan masyarakat hukum selama ini dalam literatur tidak disebut sebagai kelompok yang menuntut rekognisi, namun dalam konteks Indonesia tepat kiranya untuk menjadikan rekognisi sebagai salah satu asas pokok. Menurut Eko (2015: 39), ada lima alasan mengapa hal tersebut tepat adanya. Pertama, desa berbeda dengan kesatuan masyarakat hukum lain yang disebut dengan daerah. Kedua, desa telah eksis sebelum Indonesia berdiri. Ketiga, desa adalah bagian dari keragaman atau multikulturalisme Indonesia. Keempat, desa selama ini dieksploitasi secara tidak adil oleh negara. Kelima, konstitusi sendiri telah memberikan amanat untuk mengakui dan menghormati desa yang merupakan kesatuan masyarakat hukum adat. Secara singkat, melalui asas rekognisi, negara dan juga pihak-pihak lain (swasta, LSM, perguruan tinggi, dan sebagainya) wajib mengakui dan menghormati eksistensi desa sebagai kesatuan masyarakat hukum. Eksistensi desa tersebut mencakup hak asal-usul, pemerintahan desa, pranata dan lembaga lokal, identitas budaya, kesatuan masyarakat, prakarsa desa, dan kekayaan desa. Semua pihak di luar desa tidak lagi melakukan intervensi, pemaksaan, dan mutilasi terhadap hal-hal tersebut, melainkan sebaliknya bertindak memanfaatkan, mendukung, dan memperkuatnya. Lebih lanjut, dalam cara pandang rekognisi, dana desa dilihat sebagai instrumen untuk merehabilitasi ketidakadilan sosial-ekonomi yang selama ini dialami desa (Eko, 2015: 40-41).

Sementara itu, subsidiaritas bermakna lokalisasi penggunaan kewenangan dan pengambilan keputusan di tangan desa, terutama untuk isu dan masalah yang berskala lokal dan secara aktual memang mampu ditangani secara mandiri oleh desa. Asas subsidiaritas berbeda dengan asas residualitas yang menjiwai berbagai peraturan yang mengatur desa sebelum UU No. 6/2014. Jika dalam asas residualitas kewenangan dibagi habis antara pemerintah pusat dan pemerintah daerah sehingga desa menjadi bagian dari sistem pemerintahan kabupaten/kota yang menerima pelimpahan sisa-sisa kewenangan dari kepala daerah, maka melalui asas subsidiaritas kini ditetapkan bahwa desa kini mempuyai kewenangan sendiri. Kewenangan desa tersebut bukan lagi sekadar merupakan penyerahan dari pemerintah supradesa dan tidak boleh diintervensi oleh mereka (Eko, 2015: 4244). 


\section{Tata Kelola Jaringan}

Apakah tata kelola jaringan (network governance) itu? Bagaimana muasal konsep ini bermula? Powell menyebutkan bahwa tata kelola jaringan “... constitutes a distinct form of coordinating economic activity, which contrast and competes with markets and hierarchies" (Powell, 1990: 301). Menurut riwayatnya, konsep ini semula diambil dari teori transaksi ekonomi yang kemudian diterapkan dalam ranah tata kelola pemerintahan. Sebagai sebuah konsep di ranah ekonomi, Jones dkk. (1997) menjelaskan bahwa tata kelola jaringan dapat dikelompokkan pada dua konsep utama: (1) pola interaksi dalam pertukaran dan hubungan satu sama lain; dan (2) arus sumber daya antarunit yang independen. Konsep pertama berfokus pada pola pertukaran lateral atau horizontal, sedangkan konsep kedua berfokus pada arus sumber daya antarkelompok yang terdiri dari institusi-institusi yan masing-masing bersifat otonom.

Dari berbagai definisi mengenai tata kelola jaringan yang ada di literatur, Jones dkk. (1997: 914-915) menawarkan pengertian tata kelola jaringan sebagai seperangkat institusi-institusi otonom yang terpilih, persisten, dan terstruktur. Mereka terlibat dalam penciptaan produk atau jasa yang didasarkan pada kontrak yang bersifat implisit, mengikat secara sosial (tidak legal), dan tanpa batas pasti (open-ended) agar mampu beradaptasi terhadap kontingensi lingkungan dan mampu berkoordinasi serta mengamankan pertukaran di antara mereka. Institusi yang bergabung dalam jaringan adalah institusi yang terpilih, dalam arti hanya institusi yang tertarik untuk bergabung dalam jaringan yang bergabung di dalamnya, jadi tidak semua institusi yang ada dalam suatu industri atau sektor. Mereka juga bersifat persisten dalam arti bekerja sama secara berulang dan berkelanjutan. Sementara itu, terstruktur artinya pertukaran sumber daya di antara anggota jaringan tidak berlangsung secara acak atau seragam, melainkan terpola dengan pembagian tugas yang jelas.

Lebih lanjut, Jones dkk. (1997) menjelaskan bahwa tata kelola jaringan dapat digambarkan meliputi kumpulan kegiatan pengorganisasian dimana di dalamnya hubungan kerja sama antarpihak yang saling terkait dalam suatu kolaborasi bersifat saling membutuhkan, saling menerima akibat dan manfaat, serta memperhatikan potensi dari masing-masing pihak. Istilah “jaringan” dalam tata kelola jaringan diartikan oleh Provan dan Kenis sebagai gabungan dari tiga atau lebih organisasi otonom yang bekerja bersama tidak hanya untuk mencapai tujuan dari masing-masing organisasi namun juga mencapai tujuan bersama. Jaringan tersebut dapat diinisasi secara mandiri dan sukarela oleh anggota jaringan sendiri, namun juga dapat terbentuk karena mandat atau kontrak sebagaimana biasa terjadi kemitraan antara sektor publik dengan swasta. Karena berjejaring untuk mencapai tujuan bersama, maka jaringan mempunyai misi yang spesifik, dan misi tersebut juga dapat berubah seiring dengan waktu. Tujuan bersama dicapai dengan cara berjejaring karena biasanya tujuan tersebut terkait dengan isu kompleks yang membutuhkan koordinasi multilateral. Sementara itu, istilah "tata kelola” dalam tata kelola jaringan dimaksudkan agar jaringan tersebut berinteraksi dalam aturan main yang jelas: bagaimana sumber daya dialokasikan, bagaimana koordinasi dilakukan, dan bagaimana aksi bersama dalam jaringan secara keseluruhan dapat dikontrol (Provan dan Kenis, 2008: 231).

\section{HASIL DAN PEMBAHASAN}

\section{Tata Hubungan Desa dengan Pemerintah Supra Desa}

Kehadiran UU No. 6/2014 memberikan warna baru dalam memaknai kedudukan desa dalam sistem administrasi negara, yakni bagaimana kaitannya dengan sistem pemerintahan di atasnya yang terdiri atas pemerintah pusat dan pemerintah daerah. Sebelumnya, pada masa Orde Baru (19661998) konstruksi hubungan ketiga entitas tersebut dicirikan oleh relasi yang bersifat sentralistis, 
hierarkis, dan korporatis, di mana kekuasaan mengalir secara tak terputus dari atas ke bawah. Kedaulatan dipegang secara tunggal dan mutlak oleh pemerintah pusat. Kemudian pada era Reformasi, seiring dengan pemberlakuan otonomi daerah melalui UU No. 22 Tahun 1999 yang diperbarui dengan UU No. 32 Tahun 2004, kekuasaan tunggal tersebut mulai didesentralisasikan kepada pemerintah daerah (provinsi dan kabupaten/kota) melalui penyerahan sebagian kewenangan yang menjadi urusan daerah. Namun demikian, desa tidak mendapat bagian dari privilese otonomi daerah karena diposisikan sebagai bagian dari pemerintah kabupaten/kota yang hanya memperoleh sisa-sisa kewenangan daerah. Alhasil, desa pada masa ini direduksi tak lebih sebagai pemerintahan semu (pseudo government) yang hanya memiliki kewenangan administratif level terendah. Melalui UU No. 6/2014, cara pandang tersebut diubah dengan introduksi asas rekognisi dan subsidiaritas sebagaimana telah dijelaskan di atas.

Dalam praktiknya di lapangan, setelah hampir tiga tahun pelaksanaan UU No. 6/2014, kewenangan desa yang bertumpu pada asas rekognisi dan subsidiaritas tersebut rupanya belum terlaksana dengan baik. Bahkan, dalam tataran tertentu mengalami distorsi. Hasil kajian Pusat Kajian Desentralisasi dan Otonomi Daerah LAN (2016), misalnya, menunjukkan bahwa konstruksi hubungan kewenangan antara pemerintah supradesa dan pemerintah desa belum menempatkan desa sebagai subjek yang memiliki keleluasaan dalam menggunakan sumber daya yang menjadi kewenangannya. Hal tersebut terjadi antara lain dalam pengelolaan Dana Desa.

Berdasarkan telaah atas pengaturan pengelolaan Dana Desa, terdapat ketidakselarasan (inkonsistensi) antara UU dan regulasi turunannya sehingga menimbulkan ambiguitas dalam pengelolaan Dana Desa itu sendiri. UU Desa menegaskan bahwa dana desa menjadi salah satu sumber pendapatan desa, sekaligus menjadi hak dan kewajiban desa ("Rezim Desa”). Namun yang terjadi kemudian, Pemerintah mengeluarkan peraturan yang mengatur prioritas penggunaan Dana Desa melalui Peraturan Menteri Desa Pembangunan Daerah Tertinggal dan Transmigrasi(Permendesa PDTT) tentang Penetapan Prioritas Penggunaan Dana Desa yang diperbaharui setiap tahun (Permendesa PDTT No. 5/2015, No 21/2015, No. 22/2016jo No. 4/2017). Dengan demikian, pengaturan pengelolaan Dana Desa telah mendistorsi kewenangan desa. Penggunaan Dana Desa yang seharusnya ditentukan melalui proses deliberatif dalam musyawarah desa, telah ditentukan secara sepihak oleh Pemerintah Pusat melalui Kementerian Desa PDTT. Implikasinya jelas, pada tataran praktis, penggunaan Dana Desa pada gilirannya tidak dapat sepenuhnya mengakomodasi permasalahan, tantangan, kebutuhan yang ada di desa karena harus mengacu pada ketetapan Menteri Desa PDTT. Contoh lain peraturan dari atas yang terlalu restriktif adalah Permendagri No. 84 Tahun 2015 yang menentukan secara detail struktur organisasi pemerintah desa sehingga desa tidak punya keleluasaan untuk menyusun organisasi perangkat desa berikut nomenklaturnya yang sesuai dengan kebutuhan konteks lokal dan susunan asli (PKP2A III LAN, 2016).

Sementara itu dari sisi kelembagaan, kajian PKDOD juga menunjukkan belum adanya pengaturan yang jelas terkait peran kecamatan, baik dalam pengelolaan Dana Desa maupun dalam rangka optimalisasi implementasi UU Desa secara keseluruhan. UU Desa memang menyebutkan bahwa kewajiban binwas oleh pemerintah kabupaten/kota dapat didelegasikan kepada perangkat kecamatan. Namun dalam regulasi yang lebih teknis, pengaturan peran kecamatan tersebut masih bersifat parsial. Padahal, secara geografis, perangkat kecamatan memiliki posisi dan peluang yang cukup strategis dalam membantu memberdayakan dan memandirikan desa. Hal ini sejalan dengan temuan Pusat Inovasi Tata Pemerintahan LAN (2015) yang menemukan bahwa ruang lingkup pengawasan dan evaluasi kecamatan terhadap desa belum jelas. Ini diperparah oleh keterbatasan staf di kecamatan yang mampu membimbing desa, termasuk dalam pengelolaan keuangan desa sesuai dengan prinsip-prinsip tata kelola yang baik (good governance). 
Ke depan, perlu dikembangkan suatu model yang memberi keleluasaan pada pemerintah desa dalam pengelolaan pemerintahan dan pembangunan desa sesuai dengan kewenangan, tantangan, dan kondisi empiris yang ada di desa. Hal ini seturut dengan asas UU Desa itu sendiri, yaitu rekognisi dan subsidiaritas. Untuk itu, sebagaimana saran kebijakan dari PKP2A III LAN (2016), kepercayaan yang besar kepada desa perlu diberikan dengan mengurangi intervensi pemerintah supradesa terhadap desa. Peraturan di tingkat supradesa hanya perlu mengatur hal yang bersifat umum dan normatif, bukan hal yang bersifat teknis. Selain itu, perlu juga untuk memperkuat peran kecamatan dalam menjalankan binwas terhadap desa. Oleh karena itu, pendelegasian kewenangan dari pemerintah kabupaten/kota kepada perangkat kecamatan seharusnya juga diimbangi dengan penguatan kapasitas kecamatan itu sendiri, baik dalam aspek kelembagaan, anggaran, dan SDM.

Kelahiran UU No. 6/2014 juga membawa momentum baru untuk mendiskusikan salah satu bahasan penting dalam administrasi negara, yakni kewenangan desa. Kewenangan desa adalah hak desa untuk mengatur, mengurus, dan bertanggung jawab atas urusan pemerintahan dan kepentingan masyarakat setempat (Eko dkk, 2014: 91). UU No. 6/2014 memuat perubahan pengaturan mengenai kewenangan desa jika dibandingkan dengan peraturan sebelumnya. Selain kewenangan melekat atau atributif yang tidak disuratkan dalam UU No. 6/2014 (memilih kepala desa, membentuk susunan dan personil perangkat desa, menyelenggarakan musyawarah desa, menyusun dan menetapkan peraturan desa, dan sebagainya), di dalam UU tersebut dinyatakan bahwa desa memiliki empat kewenangan berikut: 1) kewenangan berdasarkan hak asal-usul; 2) kewenangan lokal berskala desa; 3) kewenangan yang ditugaskan oleh pemerintah pusat dan pemerintah daerah; dan 4) kewenangan lain yang ditugaskan oleh pemerintah pusat dan pemerintah daerah sesuai dengan ketentuan peraturan perundang-undangan (Eko dkk, 2014: 97-98).

Namun, karena UU No. 6/2014 tidak memuat norma yang eksplisit mengenai prinsip dan ketentuan tentang kewenangan desa (Eko dkk, 2014: 95), masih terjadi ketidakjelasan di lapangan mengenai apa yang sesungguhnya merupakan kewenangan desa. Walhasil, hal tersebut kemudian membuahkan kontestasi tafsir dan kebijakan yang berbeda. Berdasarkan hasil pemetaan kebijakan yang dilakukan PKDOD LAN (2016) terhadap peraturan pengelolaan Dana Desa, persoalan yang muncul terutama terkait konsistensi (keselarasan) penerjemahan norma hukum yang lebih tinggi ke dalam peraturan perundang-undangan yang lebih rendah. Adanya dualisme pengaturan dari dua kementerian yang mengurusi desa, yaitu Peraturan Menteri Desa PDTT No. 1 Tahun 2015 tentang Kewenangan Berdasarkan Hak Asal Usul dan Kewenangan Lokal Berskala Desa dengan Peraturan Menteri Dalam Negeri No. 44 Tahun 2016 tentang Kewenangan Desa. Merujuk pada Perpres No. 11/2015, kewenangan desa merupakan domain pengaturan Kementerian Dalam Negeri. Namun, hingga akhir tahun 2014 kebijakan yang dibutuhkan tentang ini tidak kunjung muncul. Padahal, peraturan terkait kewenangan desa sangat dibutuhkan sebagai basis penyusunan dokumen perencanaan dan penganggaran pemerintah desa.

Menanggapi situasi ini, muncul kemudian Permendesa PDTT No. 1/2015 yang secara khusus hanya mengatur soal Kewenangan Desa Berdasarkan Hak Asal-Usul dan Kewenangan Lokal Berskala Desa. Baru setahun kemudian lahir kebijakan serupa dari Kementerian Dalam Negeri sebagaimana yang dituangkan ke dalam Permedagri No. 44/2016 yang mengatur empat jenis kewenangan desa: kewenangan desa berdasarkan hak asal-usul dan kewenangan lokal berskala desa, kewenangan yang ditugaskan oleh Pemerintah, Pemerintah Daerah Propinsi, atau Pemerintah Daerah Kabupaten/Kota, dan kewenangan lain yang ditugaskan oleh Pemerintah, Pemerintah Daerah Propinsi, atau Pemerintah Daerah Kabupaten/Kota sesuai dengan ketentuan peraturan perundangundangan. Masalah muncul manakala rincian apa yang dimaksud dengan kewenangan desa berdasarkan hak asal-usul dan kewenangan lokal berskala desa antara kedua kebijakan menteri 
dari dua kementerian itu tidaklah sama. Dalam hal ini, Permendesa PDTT No. 1/2015 jauh lebih rinci dibandingkan dengan Pemendagri No. 44/2016 (Zakaria, 2017:3). Persis pada titik inilah mengapa kewenangan desa belum berjalan optimal karena Pemerintah Kabupaten/Kota dan Desa mengalami kesulitan dalam menyusun peraturan tentang daftar kewenangan desa. Temuan Survei Kementerian Koordinator Pembangunan Manusia dan Kebudayaan bersama World Bank Diagnostic terhadap 329 kabupaten menunjukkan bahwa banyak pemerintah kabupaten lambat dalam mengeluarkan peraturan yang dipersyaratkan untuk mengoptimalkan implementasi UU No. 6/2014 (dalam Agus Salim, 2016) menegaskan fakta adanya kesulitan tersebut. Hingga tahun 2016, survei ini mencatat hanya sekitar 15 persen saja kabupaten yang sudah mengeluarkan peraturan tentang daftar kewenangan desa.

Untuk mengatasi problematika tersebut, ke depan perlu ada upaya mendorong pemerintah kabupaten/kota untuk segera menyusun dan menetapkan peraturan lokal terkait daftar kewenangan desa. Kalau perlu, Kemendagri bahkan dapat memberikan sanksi administratif bagi kabupaten/ kota yang menunda atau mengulur-ulur penetapan peraturan terkait. Namun, sebelum itu, hal penting yang juga perlu didorong dan segera diwujudkan adalah merevisi Permendagri No. 44/2016 agar selaras dengan amanat UU No. 6/2014 dalam memperinci kewenangan desa, terutama kewenangan berdasarkan hak asal usul dan kewenangan lokal berskala desa.

\section{Kapasitas Pemerintah Desa}

Dalam segi tertentu, kehadiran UU Desa yang baru ini menegaskan komitmen politik dan konstitusional bahwa negara melindungi dan memberdayakan desa agar menjadi kuat, maju, mandiri, dan demokratis sehingga dapat menciptakan landasan yang kokoh dalam melaksanakan pemerintahan dan pembangunan menuju masyarakat yang adil, makmur dan sejahtera. Namun dalam implementasinya, visi mulia tersebut sudah barang tentu tidak akan terwujud tanpa ditopang oleh kapasitas dan kinerja desa dalam pemerintahan dan pembangunan. Pada titik ini, kapasitas dan kinerja desa merupakan komponen penting dalam mendorong kemandirian desa. Lalu, kapasitas pemerintahan desa seperti apakah yang menjadi prasyarat keberhasilan implementasi UU Desa untuk mencapai visi kemandirian tersebut? Sebelum menjawab pertanyaan ini, pada bagian berikut akan mendiskusikan konsep kapasitas pemerintahan desa terlebih dahulu dengan berpijak pada kewenangan pemerintahan desa.

UU No. 6/2014 menyebutkan bahwa kewenangan desa meliputi kewenangan di bidang penyelenggaraan pemerintahan desa, pelaksanaan pembangunan desa, pembinaan kemasyarakatan desa, dan pemberdayaan masyarakat desa berdasarkan prakarsa masyarakat, hak asal usul, dan adat istiadat desa. Dengan memperhatikan sejumlah kewenangan desa tersebut, maka urusan yang menjadi fokus pemerintah desa meliputi 1) urusan pemerintahan yang sudah ada berdasarkan hak asal usul; 2) urusan pemerintahan berdasarkan kewenangan lokal berskala desa; 3) urusan pemerintahan berdasarkan kewenangan yang ditugaskan oleh Pemerintah, Pemerintah Daerah Provinsi, dan Pemerintah Daerah Kabupaten/Kota; dan 4) urusan pemerintahan kewenangan lain yang ditugaskan oleh Pemerintah, Pemerintah Daerah Provinsi, dan Pemerintah Daerah Kabupaten/ Kota sesuai dengan ketentuan peraturan perundang-perundangan.

Kapasitas pemerintah desa tentunya terkait dengan kemampuan pemerintahan desa dalam melaksanakan tugas dan fungsi dalam menjalankan kewenangan sebagaimana tersebut di atas. Dalam konteks ini, pengembangan kapasitas pemerintah desa idealnya sejalan dengan kewenangan yang diemban desa sebagaimana diamanatkan oleh UU Desa. Kapasitas pemerintah desa menjadi parameter penting bagi pencapain kinerja pemerintahan desa. Dengan kata lain, pencapaian kinerja pemerintahan 
desa yang baik hanya akan terwujud jika mendapat dukungan dari individu, organisasi dan sistem yang memadai. Namun banyak pihak selama ini justru menganggap kapasitas pemerintah desa sangat terbatas, sehingga yang terjadi adalah ketergantungan terhadap pemerintah (Eko, 2014: 131).

Kepala desa menjadi aktor yang banyak disorot terkait dengan keterbatasan kompetensi ini. Ihwal kompetensi kepala desa memang memiliki banyak sisi. Studi Sutiyo dan Maharjan (2017) terhadap tiga desa di Kabupaten Purbalingga menemukan bahwa kepala desa sesungguhnya memiliki kapasitas dalam beberapa hal seperti pengetahuan akan informasi, kreativitas, fairness, daya dorong terhadap masyarakat, responsivitas, dan kepatuhan pada konsensus, namun lemah dalam hal akuntabilitas. Sementara kajian Pusat Inovasi Pelayanan Publik LAN (2015) menggarisbawahi mengenai banyaknya kepala desa dengan latar belakang pendidikan yang rendah dan Pusat Inovasi Tata Pemerintahan LAN (2015) berbicara mengenai banyaknya kepala desa yang di bawah standar (korup, suka berkonflik, tidak paham pemerintahan dan manajemen desa) serta kelemahan Permendagri No. 112 Tahun 2014 yang memberikan persyaratan terlampau mudah untuk maju sebagai calon kepala desa. Lebih jauh, kajian PKP2A III LAN Samarinda (2016) terhadap enam desa di Kabupaten Kutai Kartanegara menunjukkan minimnya kapasitas aparat desa, misalnya dalam menyusun rencana kegiatan, monitoring dan evalusai kegiatan, dan menyusun laporan pelaksanaan kegiatan. Dengan berbagai kondisi dan temuan tersebut, tidak heran jika kemudian banyak yang meragukan kapasitas pemerintah desa, terlebih manakala kini desa memiliki kewenangan sendiri, terutama dalam pengelolaan keuangan desa.

Bagaimanapun, keterbatasan kompetensi kepala desa dan aparaturnya bukanlah sepenuhnya kesalahan internal. Sebab, kondisi tersebut juga sekaligus memancing suatu pertanyaan penting tentang pelaksanaan binwas terhadap desa yang selama ini merupakan kewajiban pemda kabupaten/ kota. Baik UU No. 6/2014 maupun kebijakan pengaturan sebelumnya memang mengatur bahwa pengembangan kapasitas pemerintah desa merupakan tugas pemerintah kabupaten/kota. UU No. 6/2014 menegaskan bahwa pemerintah supradesa, baik kementerian teknis terkait maupun pemerintah lokal (kabupaten/kota) berkewajiban melakukan pembinaan dan pengawasan terhadap desa. Konsep normatif ini sesungguhnya mengarah pada fasilitasi pengembangan kapasitas desa dan supervisi melalui pengawasan untuk menjamin akuntabilitas pemerintahan desa. Namun kenyataannya, selama ini pengembangan kapasitas desa tidak memperoleh perhatian yang memadai dari pemerintah. Temuan studi awal PKDOD LAN (2015) di tahun pertama implementasi UU No. 6/2014 menegaskan kondisi keterpurukan SDM aparatur desa. Hal ini tidak hanya tercermin dari sulitnya mencari figur-figur pemimpin desa yang visioner, berwawasan luas, dengan kapasitas yang mumpuni, melainkan juga problem yang kurang lebih sama terletak pada kelompok perangkat desa dengan kapasitas yang terbatas.

Selama ini, pemerintah memang mempunyai kebijakan dan perangkat pengembangan kapasitas, misalnya melalui skema pendidikan dan pelatihan, terhadap pegawai negeri sipil baik di pusat maupun daerah. Bahkan di era otonomi daerah, pemerintah bekerja sama dengan lembaga donor untuk merancang kerangka nasional dan tindakan nyata dalam mengembangkan kapasitas pemda dalam konteks pelaksanaan desentralisasi. Namun skema yang serupa tidak masuk hingga ke level desa (Eko, 2013: 344). Seandainya selama ini amanat tersebut dilaksanakan secara baik dan berkelanjutan, niscaya kapasitas pemerintah desa bakal terus berkembang.

Dengan kata lain, sebagaimana ditunjukkan oleh studi IRE (Eko, 2014) lemahnya kapasitas dan kinerja desa bukanlah fakta yang abadi. Hal ini berpijak dari pengalaman IRE sendiri setelah menjalankan program di desa-desa dampingan ACCESS (The Austalian Community Development and Civil Society Strengthening Scheme) — yang kemudian menginspirasi para perumus UU Desamelalui pendampingan, pemanfaatan jaringan, dan pembelajaran yang berkelanjutan terbukti mampu 
mendongkrak kapasitas dan kinerja desa dalam penyelenggaraan pemerintahan dan pembangunan desa.

Lalu, bagaimana profil kapasitas pemerintah desa yang ideal? Terkait hal ini setidaknya terdapat beberapa bentuk kapasitas pemerintah desa yang dapat menjadi rujukan dan perlu dikembangkan untuk mengoptimalkan pelaksanaan kewenangan desa (Eko, 2013: 350). Pertama. kapasitas regulasi, yaitu terkait dengan kemampuan pemerintah desa mengatur kehidupan desa beserta isinya (wilayah, kekayaan, dan penduduk) dengan peraturan desa, berdasarkan kebutuhan dan aspirasi masyarakat setempat. Kedua, kapasitas ekstraksi, yaitu kemampuan mengumpulkan, mengerahkan dan mengoptimalkan pemanfaatan aset-aset desa untuk menopang kebutuhan (kepentingan) pemerintah dan warga masyarakat desa. Terkait hal ini, UU No. 6/2014 menegaskan bahwa setidaknya terdapat enam jenis aset yang dimiliki desa: a) aset fisik (kantor desa, balai dusun, jalan desa; sarana irigasi, tambatan perahu, dll); b) aset alam (tanah, sawah, hutan, perkebunan, ladang, kolam, sungai, mata air, dll); c) aset manusia (penduduk, SDM); d) aset sosial-budaya (kelompok arisan, gapoktan, gotong royong, lumbung desa, lembaga-lembaga sosial desa, dll); e) aset keuangan (tanah kas desa, BUMDes, dll); dan f) aset politik (BPD, lembaga-lembaga desa, forum warga, dll).

Ketiga, kapasitas distributif, yaitu kemampuan pemerintah desa dalam mendistribusikan sumber daya secara proporsional dan merata sesuai dengan prioritas kebutuhan masyarakat desa. Kemampuan distributif yang baik tentunya harus ditopang oleh kemampuan pemetaan sosial dan perencanaan yang memadai. Keempat, kapasitas responsif, yaitu kemampuan untuk peka atau memiliki daya tanggap terhadap aspirasi atau kebutuhan warga masyarakat desa untuk dijadikan sebagai basis dalam perencanaan kebijakan pembangunan desa. Dengan segenap kewenangannya, desa tidak lagi menjadi pelaksana tugas administratif yang diberikan pemerintah supra desa ataupun menjadi "pemadam kebakaran” guna meredakan konflik antar warga, melainkan desa kini dapat memberikan pelayanan dasar sesuai dengan kewenangan lokal berskala desa dan sumber daya dimilikinya yang diintegrasikan dalam perencanaan desa. Sebagai contoh, pelayanan penyediaan air bersih skala desa, poliklinik desa (polindes), layanan pendidikan anak usia dini (PAUD), dan seterusnya. Kelima, kapasitas berjejaring (networking) atau kerjasama, yaitu kemampuan pemerintah dan warga desa dalam mengembangkan jaringan kerjasama dengan pihak-pihak luar dalam rangka mendukung kapasitas ekstraktif. Asosiasi pemerintah desa (Apdesi) atau forum Badan Permusyawaratan Desa (BPD), misalnya, dapat digunakan sebagai wadah untuk membangun kerjasama antar desa. Demikian pula halnya dengan berbagai peluang kerjasama lain yang dapat dijajaki, misalnya dengan perguruan tinggi atau organisasi masyarakat sipil atau LSM.

Pasca implementasi UU No. 6/2014, memang terdapat sejumlah program pengembangan kapasitas pemerintah desa, baik yang dilakukan oleh pemerintah pusat maupun daerah. Kementerian Dalam Negeri, sebagai instansi pemerintah yang berwenang dalam peningkatan kapasitas pemerintah desa, mengembangkan program Peningkatan Kapasitas Aparatur Pemerintahan Desa Terpadu melalui unit Direktorat Fasilitasi Pengembangan Kapasitas Aparatur Desa Direktorat Jenderal Bina Pemerinah Desa. Sedangkan Kementerian Desa PDTT, yang memiliki kewenangan dalam urusan pemberdayaan dan pembangunan desa, mencetuskan program pelatihan Kader Pemberdaya Masyarakat Desa (KPMD) dan pelatihan pembentukan BUMDes. ${ }^{1}$ Kemudian, sejumlah pemerintah daerah juga menginisiasi program dan kegiatan serupa. Pemda Kabupaten Bogor, misalnya, menelurkan program pelatihan perencanaan desa berbasis drone. ${ }^{2}$ Namun demikian, rupanya upaya pengembangan

\footnotetext{
${ }^{1}$ Wawancara dengan Sri Daswati, Kepala Bidang Penyelenggara Program Balai Besar Pengembangan Latihan Masyarakat Jakarta, Kementerian Desa PDTT, 3 Mei 2017 di Jakarta.

${ }^{2}$ Wawancara dengan Eliyani, Bappeda Kabupaten Bogor, 18 April 2017 di Cibinong
} 
kapasitas pemerintah desa membutuhkan proses panjang dan berkesinambungan. Selain efektivitas metode/pendekatan yang digunakan dalam aneka program pengembangan kapasitas tersebut, tantangan lainnya yang muncul terkait dengan keterbatasan sumber daya, baik finansial maupun SDM (fasilitator) yang memadai. ${ }^{3}$

Selain itu, masalah yang perlu mendapat perhatian adalah polemik yang sempat muncul terkait dengan status Sekretaris Desa (Sekdes). Sebelum UU No. 6/2014, posisi sekdes ditempati oleh seorang pegawai negeri sipil (PNS). Namun kini, UU No. 6/2014 tidak mengharuskan atau mengatur secara tegas bahwa posisi Sekdes ditempati oleh PNS. Banyak tafsir yang menyebutkan bahwa UU No. 6/2014 ingin mengembalikan Sekdes pada perangkat desa non-PNS. Hal ini antara lain dilatarbelakangi oleh anggapan bahwa masuknya PNS dalam struktur pemerintah desa merupakan simbol kuatnya intervensi negara terhadap desa. Namun, kelompok pendukung agar Sekdes ditempati oleh PNS didasarkan pada satu argumen yang juga cukup masuk akal. Mereka melihat bahwa posisi Sekdes sangat vital dalam menjalankan tugas-tugas administratif penyelenggaraan pemerintahan desa. Oleh karena itu, mengganti Sekdes PNS dengan non-PNS dikhawatirkan bakal menjadi hambatan bagi penyelenggaraan pemerintahan desa.Selain itu, bercokolnya Sekdes PNS dalam struktur Pemerintah Desa tidak menjadi beban bagi anggaran desa karena statusnya sebagai PNS. Sementara untuk merekrut Sekdes baru yang non-PNS pun membutuhkan waktu dan sumber daya finansial untuk pengembangan kapasitas yang bersangkutan hingga mumpuni.

Terlepas dari polemik tentang status Sekdes di atas, LAN sesungguhnya dapat mengambil peran dalam pengembangan kapasitas pemerintah desa dengan membuka program diklat baru bagi para Sekretaris Desa, terlebih manakala status Sekdes sebagai PNS masih dipertahankan sebagaimana yang masih berlangsung di sejumlah daerah.

Tidak bisa dipungkiri, kelahiran UU No 6/2014 yang memberikan kewenangan dan dana yang besar kepada desa, seperti mengubah titik berat otonomi daerah dari kota/kabupaten ke desa (Kompas, 2 Juli 2015). Begitu pula perhatian kepada desa pun semakin besar. Menggenapi semangat dan visi UU No.6/2014, visi Nawacita juga menegaskan desa sebagai poros pembangunan nasional. Sudah barang tentu, kondisi ini memerlukan kerja yang luar biasa besar untuk mendorong kesiapan aparatur pemerintahan desa dan masyarakat desa dengan kapasitas dan kinerja yang memadai. Sebab, jika tidak, kewenangan yang besar dan kebijakan penguatan keuangan desa serta berbagai proyek dari pemerintah dan instansi lain yang berorientasi ke desa, tak akan menorehkan jejak apapun yang berkontribusi positif bagi kesejahteraan dan kemandirian desa.

\section{Desa dan Tata Kelola Jaringan}

Isu terakhir yang menarik untuk dibahas adalah kaitan desa dengan tata kelola jaringan. Teori tata kelola jaringan dapat ditilik untuk melihat bagaimana desa dapat menjawab tantangan implementasi kebijakan dan penyediaan layanan publik pasca-UU No. 6/2014. Kewenangan desa yang berpijak pada asas rekognisi dan subsidiaritas tentunya memberi ruang pada desa untuk dapat mengikuti pendekatan tata kelola jaringan, setidaknya dalam beberapa aspeknya. Terlebih manakala paradigma jaringan atau kolaborasi sangat mewarnai sebagian besar pokok-pokok dalam UU No. 6/2014. Dengan asas rekognisi dan subsidiaritas, relasi desa dan berbagai institusi supradesa (pemerintah pusat, pemerintah provinsi, dan pemerintah kabupaten) tidak lagi bersifat subordinatif, melainkan suatu jaringan yang memberi ruang pada kolaborasi para pihak untuk bersinergi. Dengan bangunan relasi serupa itu, institusi supradesa kini tidak dapat memaksakan kehendaknya sendiri (kebijakan

\footnotetext{
${ }^{3}$ Wawancara dengan Andi Ony, Direktur Fasilitasi Pengembangan Kapasitas Aparatur Desa Ditjen Bina Pemerintahan Desa Kementerian Dalam Negeri, 19 Mei 2017 di Jakarta.
} 
dan program) terhadap desa yang dapat melemahkan kewenangan desa itu sendiri. Apa yang terjadi dalam pola relasi demikian adalah adopsi dari aspek kesetaraan dan kolaborasi dari tata kelola jaringan.

Tidak hanya berkolaborasi dengan institusi supradesa, desa juga dapat berkolaborasi dengan institusi di luar pemerintah. Bahkan, apabila mau, pemenuhan pelayanan publik di desa dapat dilakukantanpa campur tangan pemerintah. Apabila pemerintah lamban dalam penyediaan pelayanan publik, maka sudah semestinya masyarakat desa bisa berinisiatif untuk berkolaborasi dengan BUMDes, LSM, atau swasta untuk pelayanan publik terhadap mereka sendiri. Tata kelola jaringan yang diimplementasikan dalam tata kelola desa merupakan struktur interaksi antara masyarakat dengan pemerintah, Badan Usaha Milik Desa, ataupun swasta yang dilaksanakan di desa dalam pemenuhan pelayanan publik yang sudah ada ataupun dapat menumbuhkan jenis layanan yang baru.Kolaborasi yang dilaksanakan tidak terikat dengan kontrak hukum melainkan kontrak sosial, karena pada dasarnya kolaborasi tersebut bersifat saling menguntungkan.

Namun, permasalahannya adalah bagaimana menentukan model dan struktur kolaborasi yang tepat digunakan dalam pemenuhan pelayanan publik di level desa. Hendaknya, kolaborasi tidak menjadi laiknya transaksi ekonomi yang bersifat instrumentalistik dan pragmatis belaka. Dalam hal ini, prinsip-prinsip yang ada dalam Public Value Management (PVM) layak menjadi panduan. PVM merupakan model manajemen publik yang kompatibel dengan tata kelola jaringan karena di dalamnya, aktivitas pemerintah diasumsikan selalu terhubung dan saling bergantung dengan institusiinstitusi lain. Apa yang menjadi tujuan utama dari PVM adalah nilai publik (public value). Inilah yang harus dicapai secara kolaboratif dan bahu-membahu di antara pihak-pihak yang terlibat dalam kolaborasi. Manajer publik harus mampu untuk melakukan pengelolaan melalui jaringan, terbuka untuk belajar dalam berbagai cara, dan memanfaatkan sumber daya dari sumber yang beragam (Stoker dalam O’Flynn, 2007: 361-362).

Tugas manajer publik adalah mengejawantahkan nilai publik tersebut melalui pelayanan publik, regulasi, atau tindakan-tindakan lainnya. Hal tersebut tidak hanya diukur dari outcome yang dicapai, namun juga dari proses yang membuahkan kepercayaan dan keadilan. Nilai publik tidak ditentukan secara deduktif dan bukan agregat dari nilai dan kepentingan individual, melainkan ditentukan secara kolektif oleh publik itu sendiri dalam proses partisipasi yang inklusif, setara, dan dialogis (O’Flynn, 2007).

Dengan demikian, untuk mencapai nilai publik manajer-manajer publik di tingkat desa (kepala desa, perangkat desa, manajer BUMDes, pemimpin komunitas) harus mampu untuk terlibat dan bernegosiasi dengan sebanyak mungkin pihak. Mereka berdialog dengan masyarakat desa untuk menggali nilai publik yang menjadi preferensi kolektif masyarakat desa, dan mereka berhubungan dengan institusi supradesa dan pihak-pihak eksternal (swasta, LSM, perguruan tinggi) untuk mempromosikan dan mengadvokasikan nilai publik tersebut sehingga nilai publik tersebut dapat diwujudkan melalui program kolaboratif. Dengan demikian, tata kelola jaringan tidak akan terjebak pada hubungan yang bersifat instrumental dan pragmatis, melainkan mengarah kepada hubungan yang lebih bernilai karena memiliki misi untuk menciptakan nilai publik yang dapat diekpresikan dalam banyak hal dan tidak dapat diseragamkan untuk setiap desa (pelayanan publik yang lebih baik, pengurangan kemiskinan, pengayaan modal sosial, dan sebagainya).

\section{E. PENUTUP}

\section{Kesimpulan}

LAN turut terlibat dalam memikirkan desa sebagaimana terlihat dari paparan yang telah diuraikan 
di atas. Berbagai temuan studi yang dilakukan oleh LAN, terutama sejak pemberlakuan UU No. 6 Tahun 2014, dapat dikembangkan sebagai problematisasi yang memperkaya diskursus administrasi negara mengenai desa. Ada empat klaster isu strategis administrasi negara mengenai desa yang dapat dikristalisasikan dari berbagai kajian LAN. Dalam isu hubungan desa dengan pemerintah supradesa, kajian LAN menunjukkan bahwa konstruksi hubungan kewenanga di antara keduanya belum menempatkan desa sebagai subjek yang memiliki keleluasaan dalam menggunakan sumber daya yang menjadi kewenangannya, sebagaimana terlihat dari kebijakan pemerintah pusat yang terlalu restriktif mengenai penggunaan Dana Desa dan pembentukan struktur organisasi pemerintah desa. Hal ini tentu bertentangan dengan asas rekognisi dan subsidiaritas. Dalam isu kewenangan desa, ditemukan bahwa terdapat dualisme pengaturan mengenai kewenangan desa oleh dua kementerian yang mengurus desa. Ini tentu harus diurai dan diperjelas agar terdapat kesamaan persepsi oleh semua pemangku kepentingan mengenai apa persisnya yang menjadi kewenangan desa dan sejauh mana batasan dari kewenangan tersebut. Dengan demikian, desa memiliki gambaran yang jelas mengenai di mana dia dapat melakukan intervensi. Ada pun mengenai isu kapasitas desa, berbagai kajian LAN menunjukkan secara seragam bahwa kapasitas desa, terutama kepala desa dan perangkat desa, masih lemah untuk mampu menjalankan UU No.6 Tahun 2014 secara maksimal. Temuan ini hendaknya menjadi perhatian serius, terutama bagi pihak-pihak yang memiliki kemampuan untuk melakukan pendampingan, agar kegiatan pendampingan dilakukan secara lebih intensif dan merata.

Berbagai temuan dari kajian LAN yang telah dikelompokkan dalam empat isu di atas tentu diharapkan tidak hanya berhenti sebagai catatan atau sekadar meramaikan pasar wacana, namun juga ditransformasikan sebagai masukan untuk menghasilkan kebijakan tentang desa yang lebih baik dan progresif. Untuk mencapai tataran tersebut, tidak cukup hanya melakukan publikasi dan diseminasi hasil studi, melainkan diperlukan juga advokasi yang diarahkan pada pembuat kebijakan. Tradisi untuk mengkaji desa dalam berbagai perspektif yang selama ini telah dilakukan perlu dipertahankan secara berkelanjutan. Isu-isu mengenai desa dalam perspektif administrasi negara akan selalu berkembang dinamis dan ini perlu direspons oleh LAN secara intelektual karena LAN juga berperan sebagai lembaga think tank dalam bidang administrasi negara.

\section{Rekomendasi}

Berpijak pada seluruh pemaparan di atas, beberapa rekomendasi dalam rangka penguatan peran LAN terkait desa adalah sebagai berikut. Pertama, meskipun telah cukup banyak dan rutin melakukan kajian tentang desa sejak pemberlakuan UU No. 6 Tahun 2014, penguatan kegiatan kajian tetap penting untuk dilakukan. Harus diakui, selama ini hasil kajian yang dibuat LAN, baik tentang desa ataupun hal-hal lainnya, kurang memberikan kontribusi ilmiah dan kebijakan yang memadai. Hal ini terlihat dari minimnya publikasi ilmiah terpandang yang merujuk hasil kajian LAN sebagai sumber referensi. Juga dari minimnya kebijakan yang mengadopsi hasil kajian LAN. Padahal, sebagian besar dari kajian LAN adalah pembuatan model, yang intensi awalnya dimaksudkan agar menjadi kerangka umum untuk diadopsi oleh pengambil kebijakan maupun praktisi. Kecenderungan ini sebaiknya dihentikan karena selain terbukti gagal menarik perhatian untuk diadopsi juga menunjukkan miskinnya imajinasi peneliti LAN untuk merumuskan bentuk, output, dan tujuan penelitian yang lain. Selain kecenderungan modelisme tersebut, kelemahan lain dari kajian-kajian maupun kondisi penelitian secara umum di LAN antara lain: desain penelitian dan metode yang tidak matang, kegagalan untuk menangkap isu yang urgen, pelaksanaan penelitian yang terlalu singkat, kapasitas peneliti yang rendah, dan minimnya komitmen untuk mengadvokasi hasil kajian agar dapat dimanfaatkan oleh pembuat kebijakan maupun praktisi. 
Berbagai kelemahan penelitian di atas tentunya menjadi pekerjaan rumah yang harus diperbaiki karena LAN sejatinya merupakan lembaga think tank. Sebagai lembaga think tank, LAN harus senantiasa meningkatkan mutu hasil-hasil kajiannya agar tidak hanya dapat memberikan kontribusi terhadap diskursus pengembangan keilmuan, tetapi juga menjadi rujukan dalam pembaharuan kebijakan.

Kedua, selain berkontribusi melalui kajian yang dihasilkannya, LAN perlu terus untuk berperan dalam memajukan dan mengembangkan desa dalam arah dan modus yang lebih variatif. Semua tugas dan fungsi yang menjadi kewenangan LAN perlu diimplementasikan ke dalam kegiatan yang bersentuhan dengan desa. Ini sesungguhnya juga telah dilakukan, meskipun masih dalam tahap permulaan. Misalnya, di Kedeputian Inovasi Administrasi Negara(DIAN) telah dikembangkan sebuah program fasilitasi inovasi yang diciptakan khusus untuk desa dengan tajuk Street Level Innovation (SLI). Program ini telah diujicobakan pada tahun 2016 pada 14 desa di Kabupaten Cilacap dan 5 desa di Kabupaten Badung dan mampu menghasilkan 120 ide inovasi (Pusat Inovasi Kelembagaan dan Sumber Daya Aparatur, 2016). Pusat-pusat yang ada di DIAN juga memberikan kontribusi dalam hal inovasi desa melalui kajian isu strategis yang menghasilkan model inovasi pelayanan desa (Pusat Inovasi Pelayanan Publik LAN, 2015) dan alternatif desain organisasi perangkat desa yang elevan dengan kewenangan dan kebutuhan desa pasca UU No. 6/2014 (Pusat Inovasi Kelembagaan dan Sumber Daya Aparatur LAN, 2015).

Ke depan, program ini perlu diperbanyak ke lebih banyak desa di berbagai daerah. Skemaskema fasilitasi inovasi yang baru juga perlu diciptakan, sesuai dengan kebutuhan dan karakteristik desa yang beragam. Inovasi desa menjadi hal yang semakin dibutuhkan pasca UU No. 6/2014 dan faktanya memang telah banyak desa yang membuktikan mampu berinovasi (Eko, Sujito, \& Kurniawan, 2013; Kementerian Desa, Pembangunan Daerah Tertinggal, dan Transmigrasi, 2016; Tempo, 15 November 2016), namun perlu diciptakan dengan lebih masif dan merata. Meski demikian, perlu diperhatikan bahwa jangan sampai fasilitasi dan pendekatan inovasi yang dilakukan hanya bersifat teknokratis dan parsial sehingga melupakan misi penguatan demokrasi dan integrasi sosial di desa (Eko, tt: 11).Artinya, inovasi yang diciptakan perlu memperhatikan dimensi partisipasi dan sosiabilitas.

Ketiga, memperkuat peran LAN dalam memajukan dan memandirikan desa juga dapat melalui pelaksanaan diklat dan pendidikan tinggi administrasi. Di bidang diklat, LAN dapat berperan melalui pemberian pendidikan dan pelatihan untuk meningkatkan kapasitas aparat pemerintahan desa. Memang kendalanya adalah sebagian besar aparat pemerintahan desa bukanlah ASN sementara LAN hanya berwenang memberikan diklat bagi ASN. Namun, beberapa sekretaris desa adalah PNS. Mereka berhak mendapatkan diklat dari LAN dan diharapkan mampu melakukan transfer ilmu kepada jajaran aparat lain di tempatnya masing-masing. Khusus untuk pendidikan tinggi administrasi yang diselenggaran oleh STIA LAN, kontribusi terhadap desa selain dengan memberi kesempatan kepada aparat pemerintahan desa untuk mengikuti perkuliahan juga dapat dilakukan dengan pemberian mata kuliah yang terkait dengan desa seperti Kewenangan Desa, Pembangunan Desa dan Kawasan Perdesaan, Administrasi Negara Pedesaan, Demokrasi Desa, dan sebagainya.

Selain ketiga hal di atas, penguatan peran LAN juga sesungguhnya dapat diperluas lagi, yaitu antara lain dengan melakukan advokasi kebijakan atau program kegiatan terkait desa. Sebagai contoh, LAN dapat mendorong pengembangan model desa cerdas (smart village) atau mengupayakan program yang berorientasi pada pembaharuan atau revitalisasi pranata sosial desa guna mewujudkan desa inklusif. Agenda lainnya yang dapat dilakukan adalah dengan melakukan pendampingan pada desa-desa yang ditetapkan sebagai desa binaan atau desa "laboratorium” LAN. Tentunya semua agenda tersebut dijalankan dengan mempertimbangkan kemampuan, sumber daya, tantangan, peluang, dan kebutuhan desa dengan berbagai karakteristik/tipologinya yang beragam, 
baik berdasarkan tingkat perkembangannya (mandiri, maju, berkembang, tertinggal, dan sangat tertinggal) atau wilayah geografis (Jawa dan Luar Jawa).

Sebagai bagian dari sistem administrasi negara yang menempati posisi paling depan dan paling dekat dengan masyarakat, desa menempati posisi yang strategis dan bermartabat, terlebih setelah UU No. 6/2014 disahkan. Untuk itu, LAN perlu secara konsekuen memberikan perhatiannya kepada desa. Bagaimanapun struktur kelembagaan LAN di masa depan akan berubah, desa tidak boleh ditinggalkan dan diabaikan. Membaharui desa adalah bagian dari membaharui administrasi negara yang merupakan tujuan dari pembentukan LAN.

\section{DAFTAR PUSTAKA}

Chriss, James J. 2007. “Recognition”, dalam George Ritzer (ed). The Blackwell Encyclopedia of Sociology. Malden, Oxford \& Victoria: Blackwell Publishing.

Eko, Sutoro. tt. (2013). Rekonstitusi Desa: Kemandirian, Kerakyatan dan Kemakmuran. Diakses dari https://www.academia.edu/32143653/REKONSTITUSI_DESA, 12 Juli 2017. (2013). “Daerah Mengatur dan Membangun Desa” dalam Sutoro Eko Daerah Inklusif: Pembangunan, Demokrasi Lokal dan Kesejahteraan. Yogyakarta: Institute for Research and Empowerment (IRE) . (2015). Regulasi Baru, Desa Baru: Ide, Misi, dan Semangat UU Desa. Jakarta: Kementerian Desa, Pembangunan Daerah Tertinggal, dan Transmigrasi.

Eko, Sutoro, Arie Sujito, \& Borni Kurniawan. (2013). Mutiara Perubahan: Inovasi dan Emansipasi Desa dari Indonesia Timur. Sanur \& Sleman: ACCESS Phase II \& IRE Yogyakarta.

Eko, Sutoro dkk. (2014). Desa Membangun Indonesia. Sleman: Forum Pengembangan Pembaharuan Desa.

Jones, dkk. (1997). A General Theory of Network Governance: Exchange Conditions and Social Mechanism. Journal Academy of Management Review, 22 (4), 911-945

Kementerian Desa, Pembangunan Daerah Tertinggal, dan Transmigrasi. (2016). Menuju Desa Mandiri. Jakarta: Kementerian Desa, Pembangunan Daerah Tertinggal, dan Transmigrasi.

LAN. (1990). Administrasi Negara Menjelang Proses Tinggal Landas: Suatu Kumpulan Tulisan dalam Rangka Catur Windu Lembaga Administasi Negara. Jakarta: LAN.

McGann, James. (2007). Think Tanks and Policy Advice in the US: Academics, Advisors and Advocates. London: Routledge.

Miles, Matthew. B \& A. Michael Huberman. (2009). Analisis Data Kualitatif. Jakarta: UI-Press. Moleong, Lexy. J. (2007). Metodologi Penelitian Kualitatif. Bandung: Penerbit Remaja Rosdakarya. O’Flynn, Janine. (2007). From New Public Management to Public Value: Paradigmatic Change and Managerial Implications. The Australian Journal of Public Administration, 66 (3), 353-366

PKP2A III LAN. (2016). Peningkatan Kapasitas Desa. Samarinda: PKP2A III LAN.

Powell, W.W. 1990. Neither market nor hierarchy: Network forms of organization. In B. Staw \& L.L. Cummings (Eds.) Research in organizational behavior. Greenwich, CT: JAI Press. 
Provan, Keith G. dan Patrick Kenis. (2008). Modes of Network Governance: Structure, Management, and Effectiveness. Journal of Public Administration Research and Theory, 18 (2), 229-252

Pusat Inovasi Kelembagaan dan Sumber Daya Aparatur LAN (PIKSA-LAN). (2015). Desain Progresif Kontekstual Organisasi Pemerintah Desa: Menata Struktur Perangkat Desa Berdasarkan Karakteristik Kewenangannya Pasca UU Nomor 6 Tahun 2014 tentang Desa. Jakarta: Pusat Inovasi Kelembagaan dan Sumber Daya Aparatur LAN.

(2016). Pengembangan Program Inovasi bagi Birokrasi Level Terendah (Street Level Innovation). Jakarta: Pusat Inovasi Kelembagaan dan Sumber Daya Aparatur LAN.

Pusat Inovasi Pelayanan Publik LAN (PIPEL LAN). (2015). Kapita Selekta Model Inovasi Pelayanan Desa. Jakarta: Pusat Inovasi Pelayanan Publik LAN.

Pusat Inovasi Tata Pemerintahan LAN (INTAN LAN). (2015). Pengelolaan Keuangan Desa Pasca UU No. 6 Tahun 2014. Jakarta: Pusat Inovasi Tata Pemerintahan LAN.

Pusat Kajian Desentralisasi dan Otonomi Daerah LAN (PKDOD LAN). (2016). Kajian Model dan Instrumentasi Kebijakan Hubungan Kewenangan Pemerintah, Pemerintah Daerah, dan Pemerintah Desa dalam Penyelenggaraan Pemerintahan Desa. Jakarta: Pusat Kajian Desentralisasi dan Otonomi Daerah LAN.

. (2015). "Pengembangan Kapasitas Pemerintah Desa Dalam Rangka Implementasi UU No. 6/2014 tentang Desa” dalam Telaah Isu Strategis di Bidang Desentralisasi dan Otonomi Daerah. Jakarta: Pusat Kajian Desentralisasi dan Otonomi Daerah LAN.

Salim, Agus. (2016). "Hubungan Pemerintah Supradesa dengan Pemerintah Desa dalam Pengelolaan Dana Desa”. Bahan presentasi yang disampaikan dalam Diskusi Terbatas di Pusat Kajian Desentralisasi dan Otonomi Daerah LAN RI.

Soesastro, Hadi. (2008). Mengelola Sebuah “Think Tank” di Indonesia, pengantar dalam Raymond J. Struyk, Managin Think Tank: Petunjuk Praktis untuk Pendewasaan Organisasi. Jakarta: Local Government and Public Service Reform Initiave.

Stone, Diane. (2005). Think Tank and Policy Advice in Countries in Transition. Hanoi: ADB.

Sutiyo dan Keshav Lall Maharjan. (2017). Decentralization and Rural Development in Indonesia. Singapore: Springer Nature.

United Nations Development Program. (2003). Thinking the Unthinkable: From Thought to Policy. The Role of Think Tanks in Shaping Government Strategy: Experiences from Central and Eastern Europe. Bratislava: UNDP Regional Bureau for Europe and the Commonwealth of Independent States

Zakaria, Yando. (2017). Tiga Tahun Pelaksanaan UU Desa. Diakses dari https:// www.academia.edu/31363535/Tiga_Tahun_UU_Desa, 15 Februari 2017.

\section{Surat Kabar dan Website}

Kompas. (2015). “Titik Berat Otonomi Beralih ke Desa...”, 2 Juli, hal. 5.

Lembaga Administrasi Negara. (2017). http://lan.go.id/id/berita-lan/desa-harus-inovatif-denganprogram-kerja-yang-jelas, diakses 17 Juli 2017.

Tempo. (2016). Edisi Khusus “Desa Jawara di Nusantara”, 15 November 2016. 